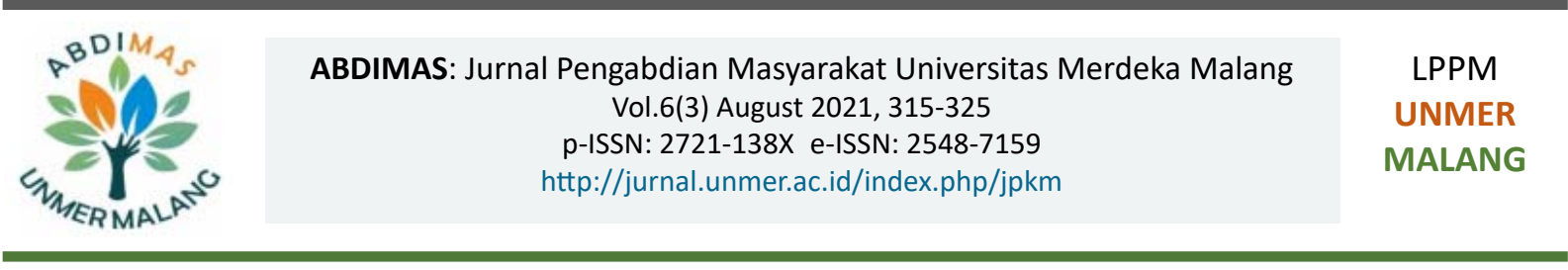

\title{
Pendampingan Penerapan loT untuk Monitoring dan Kontrol Listrik untuk Petani Hidroganik Desa Kanigoro Malang
}

\author{
Darto Darto', Agus Suprapto', Wahyu Dirgantara² \\ 'Departemen Teknik Mesin, ²Departemen Teknik Elektro, Fakultas Teknik Universitas Merdeka Malang \\ Jl. Terusan Raya Dieng No.62-64 Malang, 65146, Indonesia
}

\begin{abstract}
ARTICLE INFO
Received: 2020-12-03

Revised: 2021-03-12

Accepted: 2021-06-16

Keywords:

Electrical monitoring and control tools,

Farming profession,

Hydroganics

\section{ABSTRACT}

The farming profession in the industrial era 4.0 is considered ancient and has no potential and binafides. To change such a mindset, Community Service (PKM-Unmer Building Village) in collaboration with hydroganic farmer groups to make greenshouse and hydro-gas models accompanied by water flow monitoring (flow sensor), temperature and humidity monitoring (DHT11 sensor) and electricity control (UPS). By utilizing the loT concept in a monitoring tool that is placed in hydroganics, it can monitor the flow of water and plants in real time. To access monitoring, the cellphone must be connected to the same wifi as the device, then enter the IP address using a mobile browser. The method of implementation used consists of three stages: preparation includes a review of partner locations, coordination, and number of partners and existing facilities, pilot and, socialization. The results obtained from this activity are to accelerate and make it easier to control the hydroganics contained in the green house in real time. By utilizing a UPS to make the water pump always on, the equipment is not easily damaged if there is an electrical disturbance such as a blackout or short circuit. PKM-Unmer Building Desa produces a pilot modeled in a green house, socialization to the community and Bengkel Mimpi farmer groups and training to make simple monitoring tools.
\end{abstract}

(C)2021 Published by University of Merdeka Malang. This is an open access article distributed under the CC BY-SA 4.0 license

(https://creativecommons.org/licenses/by-sa/4.0/)

How to cite: Darto, D., Suprapto, A., \& Dirgantara, W. (2021). Pendampingan Penerapan loT untuk Monitoring dan Kontrol Listrik untuk Petani Hidroganik Desa Kanigoro Malang. Abdimas: Jurnal Pengabdian Masyarakat Universitas Merdeka Malang, 6(3), 315-325. https://doi.org/10.26905/abdimas.v6i3.5107

\section{PENDAHULUAN}

Dari $27 \%$ zona tropis dunia, Indonesia memiliki $11 \%$ wilayah tropis yang dapat ditanami serta dibudidayakan setiap tahunnya (Delima et al., 2016). Indonesia sebagai negara agraris, kebanyakan penduduknya bekerja sebagai petani. Pada era industri 4.0, pertanian menjadi salah satu bidang yang mulai ditinggalkan karena mengganggap profesi ini tidak potensional dan bonafide (Widyaningrum, 2019). Dengan menggabungkan teknik bercocok tanam hidroganik serta teknologi loT akan memudahkan 
ABDIMAS: Jurnal Pengabdian Masyarakat Universitas Merdeka Malang Volume 6, No 3, August 2021: 315-325

dalam petani dalam melakukan pemantauan tanaman jarak jauh sehingga terkesan lebih praktis dan modern.

Internet of Things (IoT) menurut Coordinator and Support Action for Global RFID-Related Activities and Standardisation adalah infrastuktur koneksi jaringan global yang menghubungkan benda fisik serta virtual melalui eksploitasi data capture dan teknologi komunikasi (Setiadi \& Muhaemin, 2018). loT dapat juga diterjemahkan sebagai kumpulan benda (things), dapat berupa hardware/embedded system dan dapat bertukar informasi yang saling terhubung di dalam sistem (Dirgantara et al., 2021). Kebutuhan dasar untuk membuat sistem (IOT) adalah dengan memanfaatkan jaringan yang ada serta internet dan pengembangan yang dibuat. Topologi jaringan yang umum dimanfaatkan pada sistem loT adalah wireless (LAN/WAN) tergantung dari kebutuhan yang ada di lapangan (Mulyanta, 2005).

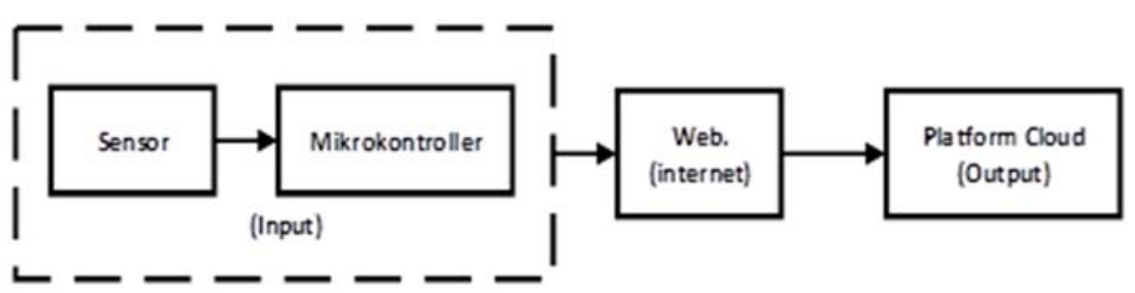

Gambar 1. Konsep Internet of Things (IoT)

Konsep sistem kontrol loT pada Gambar 1 memiliki tiga elemen, antara lain: (1) Input yang terdiri dari sensor dan mikrokontroler; (2) Proses, output dari mikrokontroler dikirim ke web melalui jaringan internet untuk dijadikan input; (3) Output merupakan platform cloud seperti android, handphone, dan laptop.

Teknik bercocok tanam hidroganik merupakan salah satu teknik bercocok tanam yang menggabungkan teknik bercocok tanam hidroponik dan akuaponik (bagian bawah kolam ikan dan atas adalah tanaman) (Rakhman et al., 2015). Kelebihan bercocok tanam mengggunakan teknik hidroganik adalah tidak perlunya memberi nutrisi tanaman serta menguras kolam ikan karena adanya sirkulasi air dari kolam ke tanaman, sehingga kotoran ikan yang menyebabkan perubahan $\mathrm{pH}$ air akan disaring oleh akar tanaman dan akar akan menggunakan kotoran ikan sebagai nutrisi (Halim, 2016; Fathulloh \& Budiana, 2015).

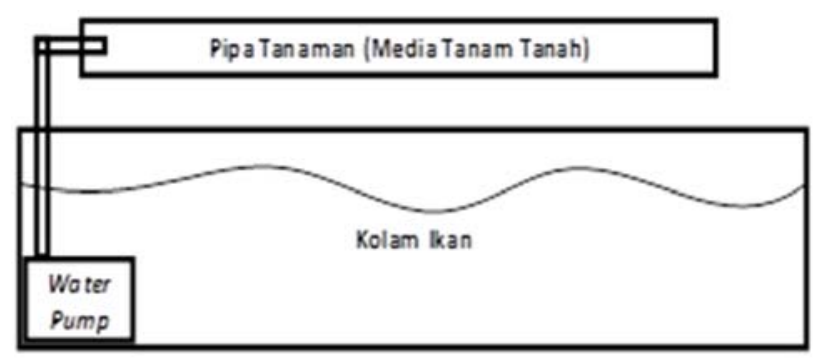

Gambar 2. Pemodelan Aliran Air Hidroganik

Media tanam tanah pada pipa tanaman berfungsi untuk menopang tananam suapaya tidak 
tumbang dan memberikan nutrisi pada tanaman. Akar tanaman yang semakin panjang berfungsi untuk filter air dari kotoran ikan dan bakteri yang akan digunakan sebagai nutrisi tambahan pada tanaman. Teknik hidroganik memiliki kendala berupa penyumbatan pada water pump yang disebabkan karena daun dari tanaman yang ada di atasnya, hal ini dikarenakan tidak adanya filter otomatis yang untuk membersihkan daun yang menyumbat.

Listrik mempunyai peranan penting bagi masyarakat, industri, pendidikan, dan pertanian. Begitu pentingnya listrik tentu mempunyai dampak dalam kehidupan sehari-hari (Saleh, 2015). Dicontohkan dalam bidang pertanian yang menggunakan teknik hidroganik, listrik dimanfaatkan sebagai penggerak water pump untuk mengalirkan air dari kolam ke pipa tanaman, memotong pipa paralon, penerangan, dan melakukan pengeboran untuk membuat green house.

Mitra Pengabdian Kepada Masyarakat (PKM Unmer Membangun Desa) merupakan kelompok tani dengan nama Bengkel Mimpi, yang beralamatkan di Desa Kanigoro Kecamatan Pagelaran Kabupaten Malang. Kelompok ini merupakan sentral hidroganik yang muncul dari program Balai Penyuluhan Pertanian (BPP) tingkat kecamatan. Lokasi ini tidak hanya digunakan sebagai tempat pertanian saja. Tempat tersebut dimanfaatkan sebagai lahan uji coba dan pelatihan bagi warga sekitar dan bahkan sampai luar daerah (Erwin, 2019).

Untuk mengontrol tanaman, khususnya aliran air pada kolam hidroganik. Kelompok tani Bengkel Mimpi menggunakan cara manual, yaitu dengan melakukan pengecekan satu persatu pada setiap kolam hidroganik dengan rentang waktu antara sepuluh sampai lima belas menit. Dengan jumlah hidroganik yang dimiliki lebih dari sepuluh, cara tersebut dianggap tidak efisien dan memakan banyak waktu dan tenaga kerja yang digunakan untuk melakukan kontrol tanaman dan aliran air kolam berjumlah tiga orang. Permasalahan lain yang dihadapi kelompok ini adalah jika terjadi pemadaman aliran listrik akan membuat aliran air menjadi terganggu serta menyebabkan $\mathrm{pH}$ air menjadi asam.

Monitoring dan kontrol listrik merupakan solusi yang digunakan untuk mengatasi permasalahan kelompok tani Bengkel Mimpi. Dengan memanfaatkan handphone dan internet yang dimiliki oleh kelompok tani Bengkel Mimpi akan bisa melakukan pengawasan pada hidroganik yang dimiliki. Data pembacaan sensor DHT11 dan flow sensor secara real time dapat diakses dengan memasukkan IP address mikrokontroller ke browser handphone. Karena menggunakan topologi jaringan Local Area Network $(L A N)$, pembacaan sensor ke handphone akan terjadi jika handphone terhubung dengan internet mulik kelompok tani Bengkel Mimpi. Untuk mengatasi pemadaman dan atau trobel pada aliran listrik pada water pump dan alat monitoring digunakan Uninterruptible Power Supply (UPS).

PKM ini mengambil tema pendampingan dan penerapan loT untuk monitoring serta kontrol listrik untuk teknik bercocok tanam hidroganik di kelompok tani Bengkel Mimpi. Tujuan penerapan IoT dan kontrol listrik sebagai media untuk mengubah pandangan (opinion) masyarakat akan profesi sebagai petani, dan mengoptimalkan kerja petani hidroganik dalam melakukan budidaya pertanian dan perikanan yang dikelola. 
ABDIMAS: Jurnal Pengabdian Masyarakat Universitas Merdeka Malang

Volume 6, No 3, August 2021: 315-325

\section{METODE}

Kegiatan Pengabdian Kepada masyarakat (PKM) Unmer Membangun Desa dilaksanakan dengan tiga tahapan.

\section{Persiapan}

Supaya kegiatan dalam pelaksanaan kegiatan PKM lebih optimal. Beberapa Langkah dilakukan, antara lain: (1) Peninjauan lokasi mitra. Langkah ini diperlukan sebagai tahap pertama untuk mengetahui lokasi, topografi wilayah dan fasilitas yang ada pada mitra. Beberapa hal yang menjadi poin penting pada tahap ini adalah: (a) Lokasi mitra PKM Unmer Membangun Desa terletak di Desa Kanigoro, Kecamatan Pagelaran, Kabupaten Malang; (b) Mitra Pendampingan berjumlah dua (Kelompok tani Bengkel Mimpi dan masyarakat umum); (c) Fasilitas yang dipakai adalah lahan dan hidroganik milik lokasi mitra (kelompok tani Bengkel Mimpi). Di lokasi mitra juga tersedia peralatan penunjang seperti projector yang akan dipakai sebagai alat sosialisasi dan pelatihan. (2) Koordinasi. Setelah mendapatkan data atau gambaran mitra, diperlukan perumusan permasalahan yang dihadapi oleh mitra, sehingga mendapatkan strategi yang optimal untuk pelaksanaan kegiatan PKM Unmer Membangun Desa; (3) Membuat prototipe alat dan sistem. Untuk meyakinkan mitra akan kegiatan PKM Unmer Membangun Desa, dibuat sebuah prototipe alat untuk mensimulasikan kondisi yang ada dilokasi mitra dengan tujuan alat yang dibuat bisa berguna dan berfungsi optimal untuk mitra.

\section{Percontohan}

Kegiatan PKM ini dilakukan dengan membuat percontohan yang dimodelkan dalam green house. Untuk memudahkan dalam pemahaman peserta dan pengimplementasian pada green house, tanaman yang dipakai dalam PKM ini adalah padi, sedangkan jenis ikan yang digunakan adalah ikan lele. Berikut adalah tahapan yang dilakukan: (1) Pembuatan green house. Green house adalah jenis rumah kaca yang dibuat untuk merawat serta menghindarkan tanaman terhadap gangguan cuaca dan hama (ASABI, n.d.). (2) Pemasangan aplikasi di lokasi mitra Tahap ini merupakan tahap terakhir terkait perancangan dan pemasangan alat sesudah pengujian prototipe alat dilakukan. Pemasangan yang dilakukan antara lain, pemasangan alat monitoring dan pemasangan penguat sinyal wifi.

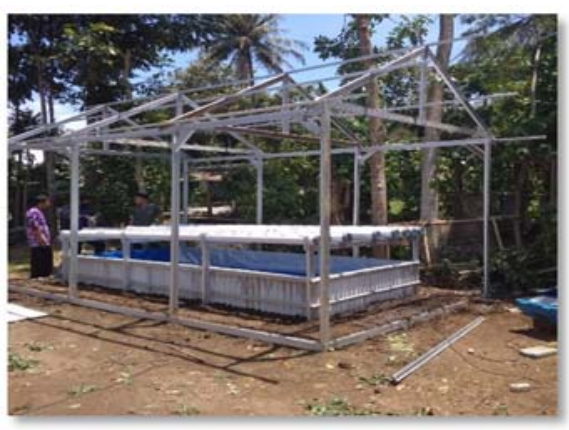

Gambar 3. Pembuatan Green House dan Hidroganik 


\section{Sosialisasi}

Sosialisasi dilakukan setelah semua komponen percontohan terpasang semua. Dengan tujuan mengubah opinion atau pandangan masyarakat akan profesi sebagai petani, serta dilakukan pelatihan pembuatan alat monitoring dan kontrol listrik. Kegiatan yang dilakukan terbagi menjadi beberapa sesi, antara lain: (1) Penjelasan sosialisasi terhadap mitra. Menjelaskan tentang maksud serta tujuan dari kegiatan Pengabdian Kepada Masyarakat Universitas Merdeka Malang Membangun Desa; (2) Penjelasan alat monitoring dan kontrol listrik. Menjelaskan terkait teknologi, alat yang dipakai dalam PKM Unmer Membangun Desa dan cara merakitnya (hardware dan software), dengan harapan peserta kegiatan memahami dan mengerti konsep dan sistem kontrol yang dibuat; (3) Pelatihan pembuatan alat monitoring. Dalam kegiatan ini digunakan sebuah modul alat yang dipakai untuk menjelaskan kepada peserta pelatihan.
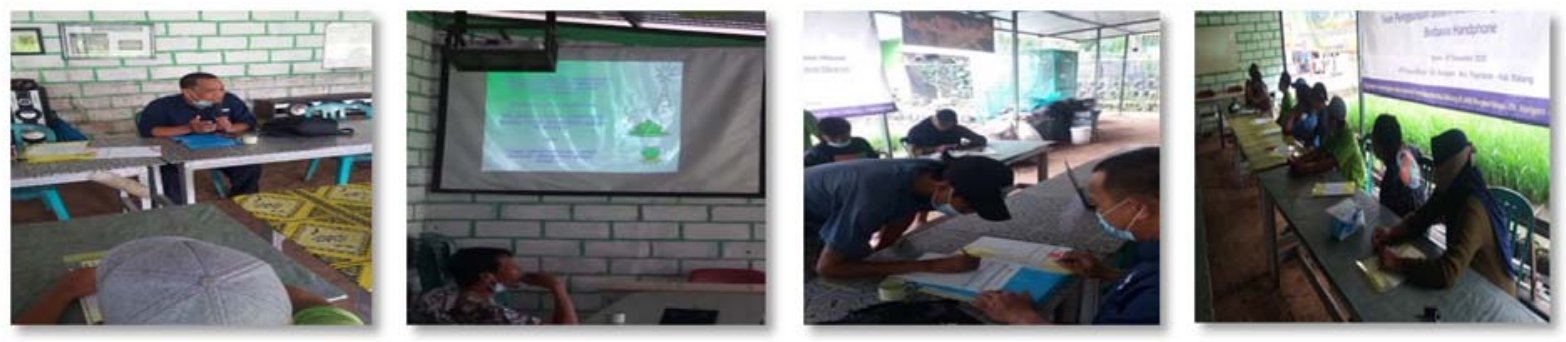

Gambar 4. Sosialisasi kegiatan PKM dengan menerapkan protokol COVID-19

Gambar 5. Absensi peserta dan tanya jawab

Demi kelancaran kegiatan sosialisasi yang dilakukan pada saat pandemi COVID-19, peserta diwajibkan mentaati aturan dari protokol COVID-19. Supaya kegiatan tidak terkesan monoton serta membosankan, maka disisipkan sebuah cerita yang mengandung unsur motivasi. Tolak ukur Keberhasilan kegiatan dan peserta PKM Unmer Membangun Desa mempunyai indikator penilaian, seperti: (1) Pelaksanaan yang sesuai dengan jadwal; (2) Jumlah peserta; dan (3) Minat kelompok mitra dari diskusi yang dilakukan.

Pada Gambar 5 memperlihatkan proses administrasi dan tanya jawab atau diskusi yang dilakukan oleh peserta. Tujuannya adalah untuk mendapatkan data serta sebagai acuan untuk membuat indikator keberhasilan kegiatan. Kegiatan sosialisasi merupakan kegiatan inti dan berfungsi sebagai pendampingan kepada kelompok mitra. Adapun yang dilakukan saat sosialisasi adalah mengenalkan kegiatan kepada kelompok mitra (petani hidroganik Desa Kanigoro-Malang) dan pendampingan dan pembimbingan untuk pemasangan serta perawatan (maintenance) alat yang dibuat.

\section{HASIL DAN PEMBAHASAN}

Kegiatan PKM Unmer Membangun Desa sudah dilaksanakan di kelompok tani hidroganik yang berlokasi di Desa Kanigoro, Kecamatan Pagelaran, Kabupaten Malang. Kegiatan selama pelaksanaan diuraikan dalam penjelasan berikut. 
ABDIMAS: Jurnal Pengabdian Masyarakat Universitas Merdeka Malang

Volume 6, No 3, August 2021: 315-325

\section{Persiapan}

Seperti penjelasan pada metode, pada tahapan ini dibagi menjadi tiga kegiatan, hal ini bertujuan untuk mengoptimalkan kegiatan yang dilakukan. Berikut penejelasan dari masing-masing tahap yang dilakukan: (1) Peninjauan lokasi mitra. Sebelum kegiatan PKM Unmer Membangun Desa dilaksanakan, perlu diadakan interaksi terhadap kelompok tani hidroganik. Hal ini diperlukan sebagai langkah awal persiapan serta peninjuan lokasi dan mendapatkan data terkait permasalahan yang dihadapi kelompok tani hidroganik (mitra), sehingga alat dan sistem yang dibuat dapat berjalan optimal.
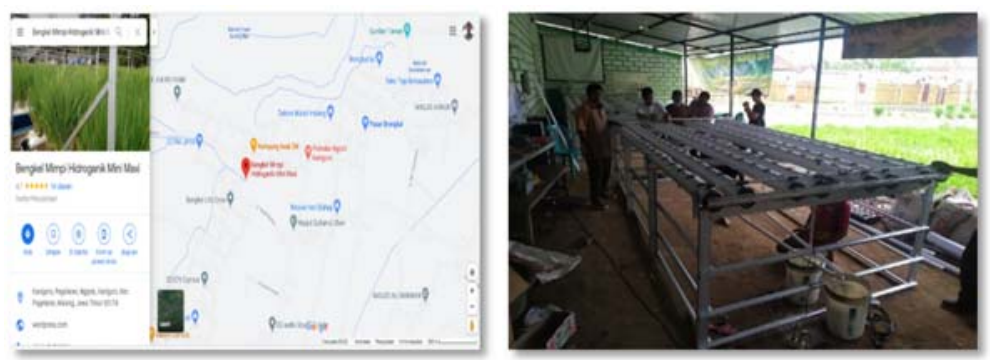

Gambar 6. Lokasi dan peninjauan kelompok tani hidroganik (pembuatan alat hidroganik)

Lokasi kelompok tani hidroganik berada di Desa Kanigoro, Kecamatan Pagelaran, Kabupaten Malang. Kegiatan pada Gambar 6 memperlihatkan kegiatan pembuatan kerangka kolam dan aliran air untuk bercocok tanam menggunakan teknik hidroganik di tempat mitra. Luas lahan yang akan diberikan oleh kelompok mitra adalah panjang \pm 5 meter dan lebar 2 meter.

\section{Koordinasi}

Setelah mendapatkan data kebutuhan dan permasalahan yang dihadapi oleh mitra, selanjutnya dilakukan koordinasi untuk mendapatkan saran juga setrategi terkait pelaksaan kegiatan PKM Unmer Membangun Desa supaya kegiatan tepat sasaran dan kegiatan mendapatkan hasil yang optimal. Koordinasi yang dilakukan mendapatkan hasil, antara lain: (1) Pelaksanaan kegiatan dilaksanakan pada bulan September 2020; (2) Mitra (kelompok tani hidroganik) memberikan lahan yang berukuran $2 \times 5$ meter sebagai lahan tempat percontohan teknologi tepat guna; (3) Alat dan sistem yang dibuat adalah sistem monitoting untuk aliran air kolam, suhu dan kelembapan udara, serta kontrol listrik.

\section{Membuat prototipe dan alat}
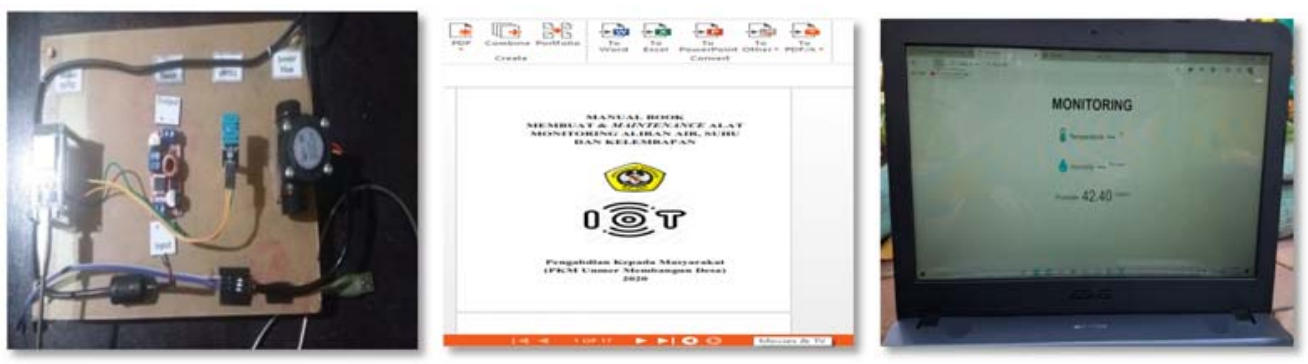

Gambar 7. Prototipe alat monitoring suhu, kelembapan dan aliran air dan manual book bentuk file PDF

Gambar 8. Tampilan pada layar laptop 
Gambar 7 merupakan modul alat monitoring yang dibuat sebagai alat peraga dalam kegiatan sosialisasi dan praktik pembuatan alat. Untuk mempermudah pemahaman peserta kegiatan sosialisasi disertakan juga sebuah buku panduan (hard copy dan soft copy) untuk merakit hardware dan software alat monitoring. Cara kerja alat, sebagai berikut: Sensor DHT11 dan Flow Sensor mengirimkan data ke modul ESP32. Modul ESP32 memproses data dari sensor yang kemudian dikirim ke website yang sudah dibuat. Untuk mengakses informasi dari website alat diperlukan koneksi jaringan yang sama dengan modul ESP32, kemudian masukkan IP address modul ESP32.

Gambar 8 Merupakan tampilan hasil monitoring yang diakses melalui laptop. Jika ingin dihubungkan dengan handphone maka langkah yang harus dilakukan adalah terhubung dengan jaringan wifi yang sama, kemudian memasukkan kode IP jaringan yang terhubung pada aplikasi Google di HP. Prototipe alat dibuat sebagai desain awal alat untuk menyelesaikan sistem yang dibuat, juga supaya terhindar dari permasalahan saat pemasangan alat di lokasi mitra. Microcontroler yang digunakan adalah ESP32, kelebihan modul ini adalah salain memiliki dua jenis tiga jenis komunikasi (kabel, bluetooth, dan wifi) sehingga sesuai jika dipakai untuk monitoring. Terdapat dua jenis sensor yang digunakan: (1) Sensor DHT11 sebagai pendeteksi kelembaban udara dan suhu; (2) Flow Sensor pendeteksi aliran air. Permasalahan utama yang dihadapi petani hidroganik adalah mengetahui water pump yang tidak bekerja dan suhu yang ada di lokasi atau tanah pertanian hidroganik, sehingga dalam prototipe alat diperlukan dua sensor tersebut.

\section{Uninterruptible Power Supply (UPS)}

Uninterruptible power supply (UPS) adalah alat untuk melindungi gangguan daya listrik seperti pemadaman dan turunnya daya. UPS menyediakan cadangan daya serta menjaga peralatan elektronik tetap aktif selama gangguan terjadi (UPS - APC INDONESIA, 2020).

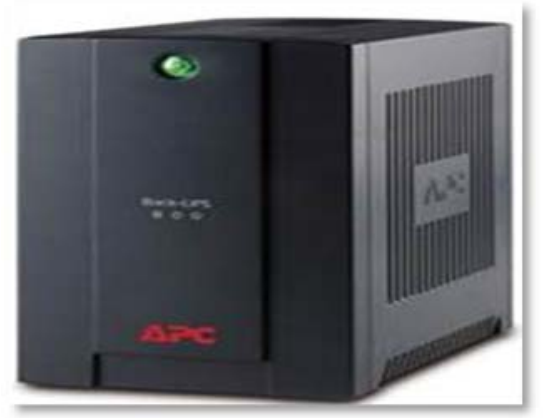

Gambar 9. Uninterruptible Power Supply (UPS)

Prinsip kerja UPS hampir sama seperti generator sehingga mempunya fungsi UPS yang diletakkan pada green house adalah untuk melindungi peralatan monitoring, modul wifi, dan water pump dari gangguan listrik seperti adanya pemadaman, konsleting listrik, dan lonjakan daya maupun penurunan daya yang bisa menyebabkan peralatan menjadi rusak. Dengan tujuan memanfaatkan UPS akan menjadikan aliran air pada hidroganik tetap mengalir sebagai mana tidak terjadi gangguan, sehingga tanaman dan ikan yang ada didalam green house tidak mengalami stres. 
ABDIMAS: Jurnal Pengabdian Masyarakat Universitas Merdeka Malang Volume 6, No 3, August 2021: 315-325

\section{Percontohan hidroganik dengan menerapkan IoT dan kontrol}

Dalam kegiatan PKM ini menghasilkan percontohan berupa green house, alat monitoring dan kontrol listrik seperti Gambar 10. Dengan memodelkan seperti pada Gambar 10, diharapkan dapat mengubah pola pikir masyarakat akan profesi petani. Petani yang dulunya identik dengan lumpur dan kotor sekarang tidak lagi seperti itu. Dengan memanfaatkan teknik hidroganik petani bisa memaksimalkan hasil yang didapatkan. Hasil yang didapatkan berupa ikan dan tanaman tanaman yang dibudidayakan (padi) seperti pada Gambar 10.
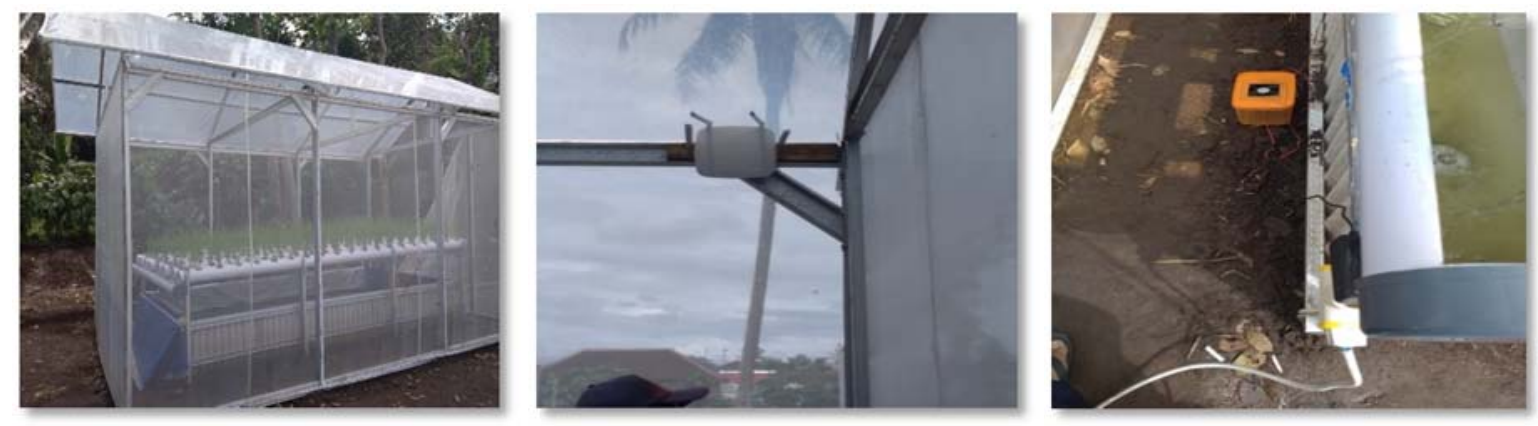

Gambar 10. Percontohan green house, alat monitoring dan kontrol listrik:

(a) Pemasangan alat monitoring sesi 1; (b) Pemasangan router; (c) Alat monitoring

Peletakan alat monitoring untuk DHT11 berada pada bawah paralon tempat tanaman, tujuannya adalah untuk memantau suhu kolam dan kelembapan udara yang ada pada green house. Sedangkan flow sensor berada pada saluran pipa water pump, dengan tujuan untuk mengetahui aliran air pada water pump mengalami penurunan aliran atau tidak. Jika terjadi penurunan aliran bisa dipastikan ada penyumbatan kotoran pada water pump.

Modul wifi pada green house berfungsi sebagai router tambahan sehingga jaringan wifi milik kelompok tani Bengkel mimpi bisa sampai ke green house. Jaringan yang dibangun menggunakan topologi jaringan Local Arean Network (LAN). Selama pengguna berada di wilayah wifi green house dan mengetahui IP yang digunakan untuk monitoring maka bisa mengetahui keadaan yang ada di dalam green house.

\section{Sosialisasi}

Untuk mengubah opini dan pandangan masyarakat akan profesi sebagai petani tidak hanya dilakukan dengan membuatkan percontohan pertanian modern, namun juga dilakukan dengan mensosialisasikan kepada kelompok tani dan masyarakat umum khususnya.

Gambar 11 merupakan tampilan website alat monitoring. Terlihat bahwa tampilan suhu dan kelembapan udara mempunyai nilai. Hal ini disebabkan pembacaan pembacaan alat dilakukan secara real time. Berbeda dengan tampilan aliran air, meskipun pembacaan sensor secara real time namun perubahan aliran air akan terlihat setiap setiap menit (per satu menit), hal inilah yang menyebabkan tampilan monitoring terlihat hanya nol (0 Liter/menit). 
Sosialisasi juga dibarengi dengan pelatihan untuk membuat software dan hardware. Hal ini bertujuan untuk mengajak dan mengajarkan kepada kelompok tani Bengkel mimpi dan masyarakat untuk memahami bagaimana mudahnya untuk membuat inovasi sederhana dan tepat guna dengan biaya yang murah.
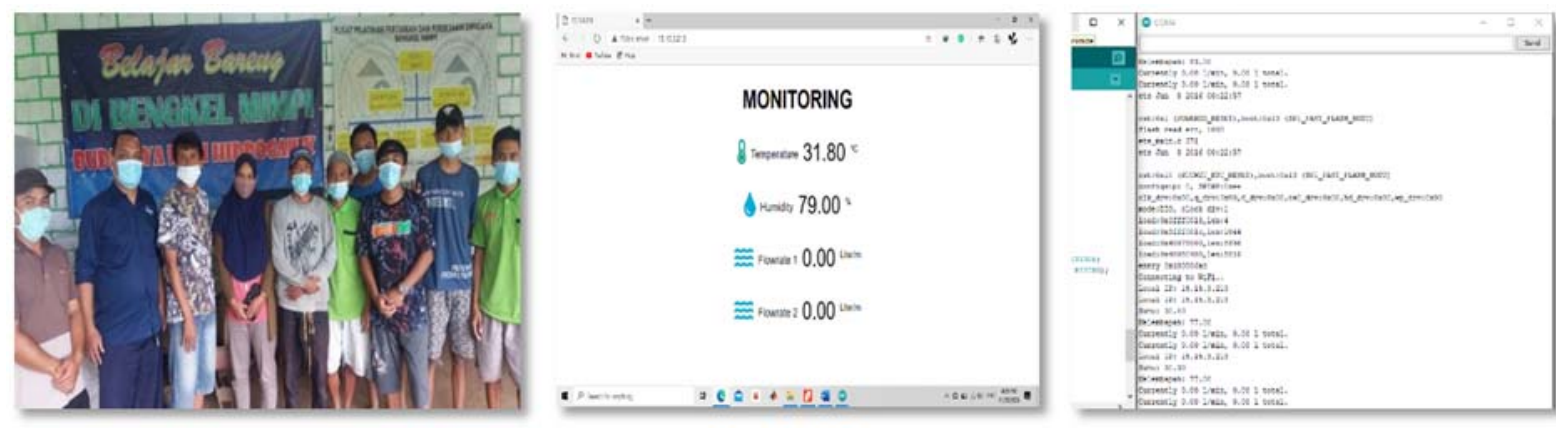

Gambar 11. Sosialisasi, hasil monitoring alat dan listing program (diakses melalui laptop): (a) Potensi hasil kegiatan; (b) Tampilan website; (c) Tampilan serial monitor arduino

Potensi yang dihasilkan dari kegiatan PKM Unmer Membangun Desa pada kelompok tani hidroganik Desa Kanigoro perlu dikembangkan. (Saputra et al., 2018).

Tabel 1. Potensi PKM Unmer Membangun Desa

\begin{tabular}{ll}
\hline $\begin{array}{c}\text { Potensi dan Ruang Ling- } \\
\text { kup }\end{array}$ & \multicolumn{1}{c}{ Keterangan } \\
\hline Sosial & $\begin{array}{l}\text { Mengubah pola pikir petani untuk memanfaatkan teknologi serta membuat teknologi } \\
\text { sederhana dan masyarakat yang menganggap pertanian itu kuno serta tidak prospektif } \\
\text { lagi menjadi berubah karena sekarang bercocok tanam mudah dengan memanfaatkan } \\
\text { teknologi sehari-hari (Putra, 2019) }\end{array}$ \\
Pendidikan & $\begin{array}{l}\text { Kelompok tani hidroganik desa kanigoro menjadi tempat rujukan serta pembelajaran } \\
\text { teknik bercocok tanam hidroganik yang memanfat teknologi. }\end{array}$ \\
Artikel IImiah & $\begin{array}{l}\text { Data yang didapatkan dari kegiatan PKM Unmer Membangun Desa bisa dijadikan seba- } \\
\text { gai bahan jurnal dan dipublikasikan sehingga informasi kegiatan bisa diakses khalayak } \\
\text { umum. }\end{array}$ \\
Usaha & Memudahkan dalam hal pengontrolan aliran air, suhu dan kelembapan sehingga tidak \\
banyak memakan waktu untuk mencari kolam mana yang mengalami masalah (trouble).
\end{tabular}

\section{SIMPULAN DAN SARAN}

Pengabdian kepada Masyarakat (PKM Unmer Membangun Desa) bertujuan untuk mengubah pola pikir petani terhadap pemanfaatan teknologi dan mengenalkan kepada masyarakat akan teknik bercocok tanam hidroganik, alat monitoring berbasis loT, dan kontrol listrik. Untuk mengontrol listrik digunakan UPS dengan maksud dan tujuan supaya water pump akan tetap dalam kondisi on serta tidak cepat rusak meskipun terjadinya pemadaman listrik atau konsleting. Dengan menggunakan handphone 
ABDIMAS: Jurnal Pengabdian Masyarakat Universitas Merdeka Malang

Volume 6, No 3, August 2021: 315-325

yang terkoneksi dengan wifi dan alat monitoring yang ada pada green house akan mempercepat serta memudahkan pemantauan kondisi aliran air dan tanaman secara real time. Data yang ditampilkan pada handphone berupa jumlah aliran air per menit, suhu dan kelembapan udara pada green house hidroganik. konsep loT yang digunakan dalam PKM ini adalah menggunakan topologi jaringan LAN, untuk menghubungkan antara handphone dan alat monitoring dapat diakses menggunakan browser dan memasukkan IP address yang sudah ditetapkan untuk alat. Teknik pembuatan greenhouse adalah pada bagian atap ditutup menggunakan plastik UV dan pada bagian bawah (dinding dan pintu) menggunakan insect screen net (jaring hidroponik dan serangga).

Beberapa Kendala yang dihadapi dalam kegiatan PKM Unmer Membangun Desa, antara lain: (1) Para peserta kegiatan PKM Unmer Membangun Desa tidak memiliki kempuan merakit hardware dan coding program. Sehingga perlu adanya tidakan lebih lanjut seperti penambahan waktu pelatihan; (2) Kelompok tani Bengkel Mimpi dalam dalam melakukan aktivitas keseharian menggunakan listrik rumah, sehingga membutuhkan daya 1300 watt. Saran untuk kegiatan selanjutnya adalah menggunakan solar cell dengan energi alternatif; (3) Perlu adanya tindak lanjut berupa kerja sama antara pihak kelompok tani Bengkel Mimpi dan Universitas Merdeka Malang (Fakultas Teknik) untuk pengembangan teknologi pertanian berbasis teknologi.

\section{UCAPAN TERIMA KASIH}

Tim PKM Unmer membangun desa mengucapkan terima kasih kepada LPPM dan Universitas Merdeka Malang yang telah memberikan hibah dalam kegiatan ini. Tak lupa pula ucapan terimakasih kepada Prodi Teknik Elektro (Lab. Intrumentasi dan Sistem Kendali) yang telah mendukung terlaksananya kegiatan ini.

\section{DAFTAR PUSTAKA}

ASABI. (n.d.). Greenhouse - ASABI. Retrieved from: https://asabi.co.id/produk/greenhouse/ (on March 29, 2021)

Delima, R., Santoso, H. B., \& Purwadi, J. (2016). Kajian aplikasi pertanian yang dikembangkan di beberapa negara Asia dan Afrika. Seminar Nasional Aplikasi Teknologi Informasi (SNATi) Yogyakarta, B19-B26.

Dirgantara, W., Arifuddin, R., \& Mujahidin, I. (2021). Monitoring akuaponik dengan Android untuk meningkatkan minat masyarakat dalam bercocok tanam di Kecamatan Porong. Abdimas: Jurnal Pengabdian Masyarakat Universitas Merdeka Malang, 6(1), 133-141. https://doi.org/10.26905/ abdimas.v6i1.5077

Erwin, M. (2019, July 18). Basiri, Penggiat Pertanian Hidroponik di Desa Kanigoro, Kecamatan Pagelaran, Kabupaten Malang. Surya Malang. Retrieved from: https://suryamalang.tribunnews. com/2019/07/18/basiri-penggiat-pertanian-hidroponik-di-desa-kanigoro-kecamatanpagelaran-kabupaten-malang

Fathulloh, A. S., \& Budiana, N. S. (2015). Akuaponik Panen Sayur Bonus Ikan. Jakarta: Penebar Swadaya Grup. 
Halim, I. J. (2016). 6 Teknik Hidroponik. Jakarta: Penebar Swadaya Grup.

Mulyanta, E. S. (2005). Pengenalan Protokol Jaringan Wireless Komputer. Yogyakarta: Penerbit Andi.

Putra, E. P. (2019, May 22). Mendorong Lahirnya Petani Milenial. Republika. Retrieved from: https:// republika.co.id/berita/prwa9q318/mendorong-lahirnya-petani-milenial

Rakhman, A., Lanya, B., Rosadi, R. A. B., \& Kadir, M. Z. (2015). Pertumbuhan tanaman sawi menggunakan sistem hidroponik dan akuaponik. Jurnal Teknik Pertanian Lampung, 4(4), 245-254.

Saleh, A. (2015). Implementasi metode klasifikasi Naive Bayes dalam memprediksi besarnya penggunaan listrik rumah tangga. Creative Information Technology Journal (CITEC Journal), 2(3), 207-217. https://doi.org/10.24076/citec.2015v2i3.49

Saputra, H., Rudianto, R., Setiawan, D., \& Nugroho, R. A. (2018). Desa Wisata Hidroponik sebagai upaya pemberdayaan masyarakat Desa Sidomulyo Kecamatan Anggana Kabupaten Kutai Kartanegara. JPKM: Jurnal Pengabdian kepada Masyarakat, 24(1), 587-593. https://doi. org/10.24114/jpkm.v24i1.9656

Setiadi, D., \& Muhaemin, M. N. A. (2018). Penerapan Internet Of Things (loT) pada sistem monitoring irigasi (smart irigasi). Infotronik: Jurnal Teknologi Informasi dan Elektronika, 3(2), 95-102. https://doi.org/10.32897/infotronik.2018.3.2.108

UPS - APC INDONESIA. (2020, November 24). UPS untuk UKM. APC Indonesia. Retrieved from: https:// www.apcindonesia.id/tag/ups/ (on March 29, 2021)

Widyaningrum, L. (2019, September 4). Jakarta Harus Tiru Singapura Soal Konsep Bertani anpa Lahan. ERA. Retrieved from: https://www.era.id/read/p4Upqm-jakarta-harus-tiru-singapura-soalkonsep-bertani-tanpa-lahan 